\title{
Barriers to Parent-Child Book Reading in Early Childhood
}

\author{
Catherine L. Taylor ${ }^{1,2}$ - Stephen R. Zubrick ${ }^{1,2}$ • \\ Daniel Christensen ${ }^{1}$
}

Published online: 26 September 2016

(c) The Author(s) 2016. This article is published with open access at Springerlink.com

\begin{abstract}
Book reading is one of the most important investments that parents make in their children's literacy development. This study investigated risk factors associated with the absence of book reading at ages 2, 4 and 6 years. A holistic view of the multiple ecologies of child development guided the study across a sample of approximately 4000 children from the Longitudinal Study of Australian Children. Eight potential risk factors for the absence of book reading were examined in a multivariate logistic regression analysis and in a cumulative risk approach. The magnitude of association between individual risk factors and the absence of book reading varied at different ages. However, across all ages, there was a consistent association between multiple risk exposures and the absence of book reading. The results suggest that the absence of book reading may serve as a red flag for multiple disadvantages. For this reason, parent-child book reading interventions alone are unlikely to meet the needs of children and families for whom the absence of book reading is an outcome of psychosocial risk factors.
\end{abstract}

This paper uses unit record data from Growing Up in Australia: The Longitudinal Study of Australian Children (LSAC). The LSAC study is conducted in partnership between the Department of Social Services (DSS), the Australian Institute of Family Studies (AIFS) and the Australian Bureau of Statistics (ABS). The findings and views reported in this paper are those of the authors and should not be attributed to the DSS, AIFS or the ABS.

Catherine L. Taylor

cate.taylor@telethonkids.org.au

Stephen R. Zubrick

stephen.zubrick@telethonkids.org.au

Daniel Christensen

daniel.christensen@telethonkids.org.au

1 Telethon Kids Institute, 100 Roberts Rd, Subiaco, WA 6008, Australia

2 Graduate School of Education, University of Western Australia, Perth, WA 6009, Australia 
Keywords Parent-child book reading · Home learning environment · Psychosocial risk factors - Multiple disadvantages - Longitudinal Study of Australian Children

Résumé La lecture de livres est l'un des plus importants investissements que peuvent faire les parents pour le développement de la littéracie de leurs enfants. Cette étude porte sur les facteurs de risque associés à l'absence de lecture de livres chez les enfants de 2, 4 et 6 ans. Une perspective holistique des multiples écologies du développement de l'enfant a guidé l'étude à travers un échantillon d'environ 4000 enfants provenant de l'Étude longitudinale des enfants australiens. Huit facteurs de risque potentiels liés à l'absence de lecture de livres ont été examinés dans une analyse de régression logistique à variables multiples et une approche de risque cumulatif. La magnitude de l'association entre les facteurs de risque individuels et l'absence de lecture de livres varie aux différents âges. Toutefois, à tous les âges, il y a une association constante entre l'exposition à des risques multiples et l'absence de lecture de livres. Les résultats suggèrent que l'absence de lecture de livres peut servir de signal d'alarme de désavantages multiples. Pour cette raison, il est improbable que les interventions sur la lecture de livres aux enfants par les parents puissent répondre seules aux besoins des enfants et des familles pour lesquels l'absence de lecture de livres est un résultat de facteurs de risque psychosociaux.

Resumen La lectura de libros es una de las inversiones más importantes que los padres pueden hacer en el desarrollo literario de sus hijos/as. Este estudio investigó factores de riesgo asociados con la ausencia de lectura de libros en las edades de dos, cuatro y seis años. El estudio estuvo guiado por una visión holística de las ecologías múltiples del desarrollo infantil en una muestra de aproximadamente cuatro mil niños/as que hicieron parte del Estudio Longitudinal de Niños/as Australianos. Se examinaron ocho posibles factores de riesgo de la ausencia de lectura en un análisis multivariado de regresión logística y en un enfoque de riesgo acumulado. La magnitud de la asociación entre factores de riesgo individuales y la ausencia de lectura de libros varían en diferentes edades. Sin embargo, en todas las edades se observó una relación consistente entre exposiciones de riesgo múltiple y la ausencia de lectura. Los resultados sugieren que la ausencia de lectura puede indicar una señal de alarma para diferentes situaciones de desventaja. Por esta razón, las medidas aisladas de intervención de lectura de padres a sus hijos/as no son suficientes para suplir las necesidades de niños/as y familias para quienes la ausencia de lectura de libros es el resultado de factores de riesgo psicosocial.

\section{Introduction}

Parent-child book reading is one of the most important investments that parents make in their children's language, literacy and lifelong learning (Kalb and van Ours 2014; Mistry et al. 2010; Thomas 2006). Regular reading to children and access to books is an essential component of a stimulating home learning environment 
(Powell and Diamond 2012). Shared book reading promotes oral language and provides developmental bridging from oral language to literacy (Senechal and LeFevre 2002). A recent study using functional magnetic resonance imaging (fMRI) identified a neurobiological correlate of parent-child book reading. When listening to stories, children with greater exposure to home reading showed higher activation of brain regions associated with language and literacy (Hutton et al. 2015).

A consistent finding in the literature is that regular parent-child book reading lessens the risk for low school readiness associated with socio-economic disadvantage and the cluster of psychosocial risk exposures associated with it (Duncan et al. 2007; Lugo-Gil and Tamis-LeMonda 2008; Mistry et al. 2010; Australian Bureau of Statistics 2015). This is encouraging for early childhood professionals, whose sphere of influence centres on enhancing parent-child interactions and home learning experiences (Guralnick 2013; Knoche et al. 2012).

Promoting parent-child book reading is an uncontested essential role for early childhood professionals and is championed in early childhood education (United Nations Educational Scientific and Cultural Organisation, UNESCO 2015) and health policies (High et al. 2014). The aim of this study is to provide early childhood professionals with contextual information about why some parents do not read to their children that will enhance their early intervention and prevention practices.

This study had three aims: first, to document parent-child book reading behaviours at ages 2, 4 and 6 years; second, to investigate psychosocial risk factors for the absence of parent-child book reading at home; and third, to investigate the cumulative impact of psychosocial risk factors on the absence of parent-child book reading at home.

\section{Methods}

\section{Participants}

The study sample was comprised of children who participated in the Longitudinal Study of Australian Children (LSAC) at ages 2, 4 and 6.

The LSAC is a national longitudinal study that commenced in 2004 (Edwards 2012; Misson and Sipthorp 2007; Soloff et al. 2005, 2006). The study uses a crosssequential design of biennial face-to-face visits with the family and study child.

In this study, we used data from the Baby Cohort collected across three waves. The ages of the children at each wave are described in Table 1. For simplicity, we refer to the children at the three waves as aged 2, 4 and 6 years. The Baby Cohort

Table 1 Sample size at each wave, children's ages

\begin{tabular}{llll}
\hline Wave & $N$ & \multicolumn{2}{l}{ Child's age in months } \\
\cline { 3 - 4 } & & Median & Range \\
\hline 2 & 4606 & 34 & $27-46$ \\
3 & 4386 & 58 & $49-70$ \\
4 & 4242 & 82 & $73-93$ \\
\hline
\end{tabular}


comprised 4606 children at 2 years, 4386 children at 4 years and 4242 children at 6 years.

The LSAC sampling frame was extracted from the Medicare Australia enrolment database. The initial study sample was designed to be representative of Australian children within the selected age cohort, proportional to the regional distribution of children in the Australian population (Soloff et al. 2005, 2006).

The study entailed a two-stage clustered design, first selecting postcodes then children within postcodes. Stratification was used to ensure proportional geographic representation for states/territories and capital city statistical division/rest of state areas.

Analyses show that the initial sample was broadly representative of the general Australian population when compared with 2001 Census data, but slightly underrepresentative of families who were single-parent, non-English speaking and living in rental properties. Attrition somewhat increased these biases (Misson and Sipthorp 2007; Taylor et al. 2013).

The analytic sample for the analyses in this paper varies because of missing data at wave or item level.

\section{Ethics}

The study has ethics approval from the Australian Institute of Family Studies Ethics Committee. The Ethics Committee is registered with the Australian Health Ethics Committee, a subcommittee of the National Health and Medical Research Council (NHMRC). Caregivers gave written informed consent to the survey. As the study children were all minors at the time these data were collected, written informed consent was obtained from the caregiver on behalf of each of the study children. The signed consent forms are retained by the field agency, the Australian Bureau of Statistics.

\section{Measures}

\section{Outcomes}

The outcome of interest in this paper is whether or not the study child was read to by their main carer or another adult in the family in the week prior to the survey. This information was collected from parent 1 (the LSAC survey respondent, typically the main carer) when the child was aged 2, 4 and 6. Parents were asked to indicate the frequency with which children were read to in the last week on a 4-point scale ranging from "none" to "every day (6-7 days)". Reading to children is a normative behaviour, and the absence of this behaviour is a concern. In this paper, we have a particular focus on children not read to whatsoever (Table 2).

From ages 2 to 6 , the majority of children were read to 6 or 7 days a week. A small proportion of children were not read to at all.

Two other measures of reading behaviour were also assessed in this study; the amount of time the study child is usually read to in a sitting, and the number of children's books in the home. The duration of reading in a sitting is measured on an 
Table 2 Read to study child in last week

\begin{tabular}{lccc}
\hline Read to study child in last week & \multicolumn{3}{l}{ Age of study child (years) } \\
\cline { 2 - 4 } & 2 & 4 & 6 \\
\hline Not in the past week & $261(5.67 \%)$ & $251(5.72 \%)$ & $324(7.64 \%)$ \\
1 or 2 days & $539(11.7 \%)$ & $646(14.73 \%)$ & $588(13.86 \%)$ \\
$3-5$ days & $970(21.06 \%)$ & $1134(25.86 \%)$ & $1277(30.1 \%)$ \\
$6-7$ days & $2836(61.57 \%)$ & $2354(53.68 \%)$ & $2048(48.28 \%)$ \\
\hline
\end{tabular}

8-point scale ranging from "child doesn't like to be read to at all" to "more than 60 min" (Table 3).

At ages 2 and 4, the most commonly reported category of reading to the study child was $6-10 \mathrm{~min}$ in a sitting. At age 6 , the most common category was 11-15 min per sitting.

It was relatively unlikely at any age that parents would report their child doesn't like being read to, or was read to for more than $41 \mathrm{~min}$ in a sitting.

The number of children's books in the home was assessed on a 5-point scale, ranging from "none" to "more than 30". The majority of parents reported more than 30 children's books in the house (Table 4).

\section{Barriers to Reading}

This study considered eight barriers to children being read to: two child factors (Indigenous study child and low child task attention), three maternal factors (elevated maternal psychological distress, low maternal education and low maternal warmth) and three family factors (mother non-English-speaking background, single mother family and low family income).

Table 3 Minutes study child usually read to in a sitting

\begin{tabular}{lccc}
\hline Minutes study child usually read to in a sitting & \multicolumn{4}{l}{ Age of study child (years) } \\
\cline { 2 - 4 } & 2 & 4 & 6 \\
\hline Child doesn't like to be read to at all & $71(1.54 \%)$ & $3(0.07 \%)$ & $113(2.66 \%)$ \\
$<5 \mathrm{~min}$ & $508(11.03 \%)$ & $271(6.56 \%)$ & $243(5.73 \%)$ \\
$6-10 \mathrm{~min}$ & $1690(36.69 \%)$ & $1349(32.63 \%)$ & $1219(28.74 \%)$ \\
$11-15 \mathrm{~min}$ & $1161(25.21 \%)$ & $1229(29.73 \%)$ & $1362(32.11 \%)$ \\
$16-20 \mathrm{~min}$ & $708(15.37 \%)$ & $779(18.84 \%)$ & $834(19.66 \%)$ \\
$21-40 \mathrm{~min}$ & $431(9.36 \%)$ & $465(11.25 \%)$ & $425(10.02 \%)$ \\
$41-60 \mathrm{~min}$ & $28(0.61 \%)$ & $32(0.77 \%)$ & $26(0.61 \%)$ \\
$>60 \mathrm{~min}$ & $9(0.2 \%)$ & $6(0.15 \%)$ & $15(0.35 \%)$ \\
\hline
\end{tabular}


Table 4 Children's books in house

\begin{tabular}{lcrr}
\hline $\begin{array}{l}\text { Number of children's } \\
\text { books in house }\end{array}$ & \multicolumn{3}{l}{ Age of study child (years) } \\
\cline { 2 - 4 } & 2 & 4 & 6 \\
\hline None & $20(0.43 \%)$ & $8(0.18 \%)$ & $6(0.14 \%)$ \\
$01-10$ & $264(5.73 \%)$ & $136(3.1 \%)$ & $119(2.81 \%)$ \\
$11-20$ & $468(10.16 \%)$ & $243(5.54 \%)$ & $218(5.14 \%)$ \\
$21-30$ & $532(11.55 \%)$ & $367(8.37 \%)$ & $304(7.17 \%)$ \\
$>30$ & $3322(72.12 \%)$ & $3631(82.81 \%)$ & $3590(84.63 \%)$ \\
\hline
\end{tabular}

The selection of measures used in this paper was guided by the LSAC ethos, empirical and/or theoretical associations with book reading, and our previous work in the area.

For the purposes of this analysis, we dichotomised each variable into an "at-risk" group (i.e. highest risk group) and a reference group (i.e. lowest risk group).

Study child minority race has previously been identified as an independent risk factors for low receptive language ability. A small proportion of children were of Indigenous (Aboriginal and/or Torres Strait Islander) descent and were coded to distinguish them from those who were not.

Task attentiveness refers to children's ability to regulate their attention in order to persist with tasks without distraction. Sawyer et al. (2015) described a method for deriving task attentiveness in their paper. Task attentiveness was measured with a total of six items at age 2 (scores ranging 6-33) and five items at age 4 and age 6 (scores ranging 5-27). We defined children in the bottom $15 \%$ at each age as having "low task attentiveness".

In this study, we used the Kessler-6 (K6) scale to measure maternal non-specific psychological distress. Women with scores of eight or more were classified as having symptomatic psychological distress (i.e. classified as high risk). This threshold is consistent with other studies (Lawrence et al. 2011; Strazdins et al. 2007, 2010) using the K6.

In Australia, at the time of this study, 10 years of education was compulsorily mandated. Mothers with year 11 or less were considered at risk.

The parenting warmth of the mother was measured in a self-complete form developed for the LSAC (Zubrick et al. 2008, 2014). Maternal warmth was measured at each wave by 6 questions (e.g. "In the last 6 months, how often did you feel close to the child both when he/she was happy and when he/she was upset?"). Responses to each item were on a 5-point Likert scale, ranging from "almost never" to "always/almost always". Items for each measure were summed to create a composite score with higher levels representing more positive parenting characteristics. Children of mothers in the lowest $15 \%$ of parenting warmth were considered at risk.

As the focus of this study was explicitly on English language development and because language development is known to vary where more than one language is spoken in the home, we used the mother's non-English-speaking background 
(NESB) as a general indicator for language other than English spoken in the household at 4 years.

Single mother families were considered at risk because these parents face a number of resource challenges.

Families were asked to report their total weekly family income from all sources. Families in the lowest $15 \%$ at each age were considered at risk.

Each risk factor was dichotomised, which allowed the estimation of the total number of risks each child was exposed to at ages 2, 4 and 6. This gave each child a potential number of risks from 0 to 8 at each age.

\section{Statistical Analysis}

All analyses were conducted in SAS version 9.4 (SAS Institute Inc. 2002-2012). Logistic regression was used to estimate the unadjusted and adjusted odds of children not being read to at ages 2, 4 and 6. Logistic regression was used to estimate the unadjusted odds ratios (ORs) and adjusted odds ratios (aORs) of children not being read to at ages 2, 4 and 6 . Odds ratios are a relative measure of effect which allows a comparison to be made between the groups classified as "at risk" on any measured variable relative to the comparison group of "not at risk". The odds ratios in these analyses indicate the relative likelihood that that parentchild book reading does not occur in the "at-risk" group. The adjusted odds ratios (aOR) control for any additional variables included in any logistic regression model.

\section{Results}

The distribution of risks for not being read to at ages 2, 4 and 6 is described in Table 5. Risks ranged in prevalence from Indigenous status $(4.5 \%)$ to maternal education year 11 school or less $(29.6 \%$ at child age 2$)$.

Table 6 describes the adjusted associations between the individual risk factors and the study child not being read to. At age 2, maternal NESB status (aOR: 4.0), low maternal education (aOR: 2.8), study child Indigeneity (aOR: 2.8), low task attention (aOR: 2.4) and low family income status (aOR: 1.7) were all associated with increased likelihood of the study child not being read to.

At age 4, study child Indigeneity (aOR: 2.7), maternal education (aOR: 2.6), maternal NESB status (aOR: 2.3), low maternal warmth (aOR: 1.8), single mother family status (aOR: 1.8), low task attention (aOR: 1.7) and low family income status (aOR: 1.6) were all associated with increased likelihood of the study child not being read to.

At age 6, maternal education (aOR: 2.0), low maternal warmth (aOR: 1.8) and maternal NESB status (aOR: 1.4) were all associated with increased likelihood of the study child not being read to at age 6 .

The pattern of statistical significance for individual risk factors varied between ages, but confidence intervals tended to overlap and little can be said about the changing pattern of significance between ages. 
Table 5 Barriers to reading, ages 2, 4 and 6

\begin{tabular}{lccc}
\hline Barriers to reading & $\begin{array}{l}\text { Proportion of } \\
\text { sample at age } \\
2(\%)\end{array}$ & $\begin{array}{l}\text { Proportion of } \\
\text { sample at age } \\
4(\%)\end{array}$ & $\begin{array}{l}\text { Proportion of } \\
\text { sample at age } \\
6(\%)\end{array}$ \\
\hline Study Child & & & \\
Indigenous SC & 4.5 & 4.5 & 4.5 \\
Low task attention & 14.64 & 13.93 & 12.12 \\
Mother & & & \\
Elevated maternal psychological distress (K6 8+) & 8.92 & 9.66 & 10.67 \\
Maternal education year 11 school or less & 29.56 & 28.41 & 27.23 \\
Low maternal warmth & 15.88 & 10.81 & 10.93 \\
Family & & & 12.54 \\
Mother NESB & 13.43 & 12.57 & 10.42 \\
Single mother family & 9.83 & 9.46 & 14.98 \\
Low family income & 14.98 & 14.99 & \\
\hline
\end{tabular}

Table 6 Adjusted odds ratios, at ages 2, 4 and 6

\begin{tabular}{llll}
\hline Risk factor & $\begin{array}{l}\text { Odds ratio, not being } \\
\text { read to age } 2\end{array}$ & $\begin{array}{l}\text { Odds ratio, not being } \\
\text { read to age } 4\end{array}$ & $\begin{array}{l}\text { Odds ratio, not being } \\
\text { read to age } 6\end{array}$ \\
\hline $\begin{array}{l}\text { Study child } \\
\text { Indigenous SC }\end{array}$ & $2.77(1.28,6.01)^{* *}$ & $2.66(1.5,4.72)^{* * *}$ & $1.45(0.82,2.58)$ n.s. \\
$\begin{array}{l}\text { Task attention low } \\
\text { Mother }\end{array}$ & $2.44(1.59,3.74)^{* * *}$ & $1.72(1.18,2.51)^{* *}$ & $0.71(0.47,1.07)$ n.s. \\
$\begin{array}{l}\text { Elevated maternal } \\
\text { psychological distress } \\
\text { (K6 8+) }\end{array}$ & $1.5(0.86,2.6)$ n.s. & $1.41(0.91,2.19)$ n.s. & $1.22(0.85,1.77)$ n.s. \\
$\begin{array}{l}\text { Low maternal education } \\
\text { Low maternal warmth }\end{array}$ & $2.83(1.91,4.18) * * *$ & $2.57(1.85,3.56)^{* * *}$ & $1.99(1.53,2.59)^{* * *}$ \\
$\begin{array}{l}\text { Family } \\
\text { Mother NESB }\end{array}$ & $1.2(0.74,1.93)$ n.s. & $1.77(1.17,2.67)^{* *}$ & $1.83(1.31,2.57)^{* * *}$ \\
$\begin{array}{l}\text { Single mother family } \\
\text { Low family income }\end{array}$ & $1.24(0.66,2.3)$ n.s. & $1.76(1.09,2.83)^{*}$ & $1.36(0.91,2.05)$ n.s. \\
\hline
\end{tabular}

n.s. non-significant

$* P<.05$; ** $P<.01$; *** $P<.001$

The distribution of risk exposures is different between children read to and not read to at ages 2, 4 and 6 (Figs. 1, 2, 3, respectively). Only $9.6 \%$ of children not read to at age 2 were exposed to 0 risks, compared with $38.9 \%$ of children read to at least once. $62.1 \%$ of children not read to at age 2 experienced 2 or more risks, compared with only $25.9 \%$ of children read to at least once in the last week.

$18.7 \%$ of children not read at age 4 experienced 0 risks, compared with over $42.3 \%$ of children read to at least once. $54.6 \%$ of children not read to at age 4 


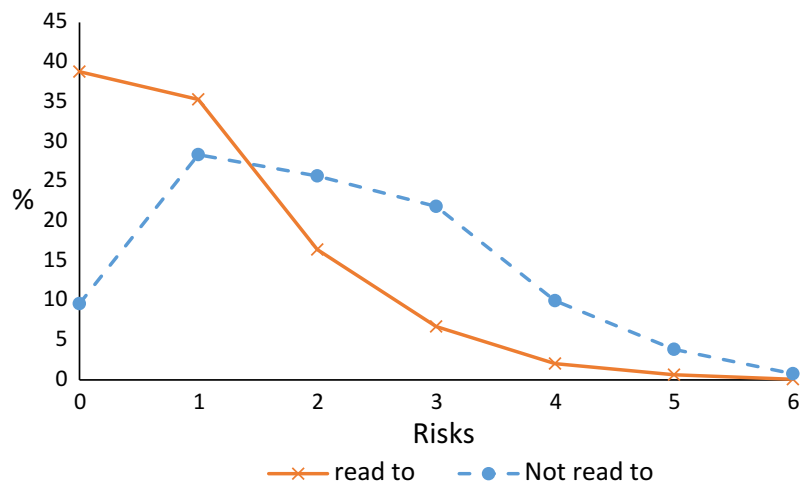

Fig. 1 Number of risks by reading status at age 2

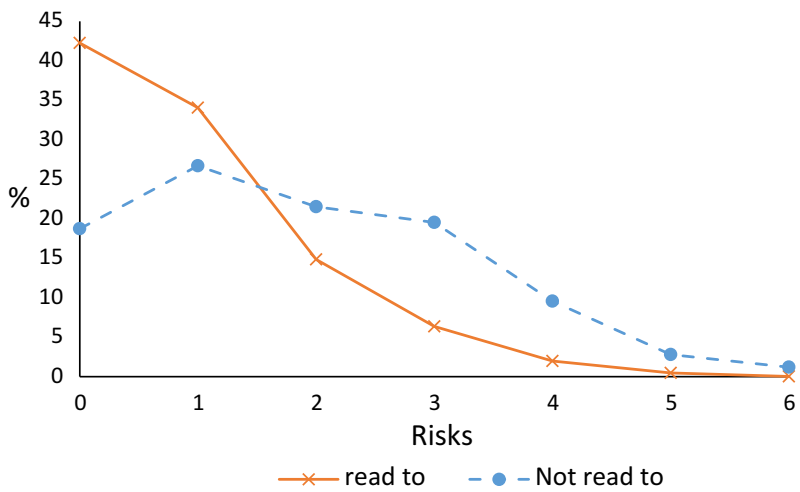

Fig. 2 Number of risks by reading status at age 4

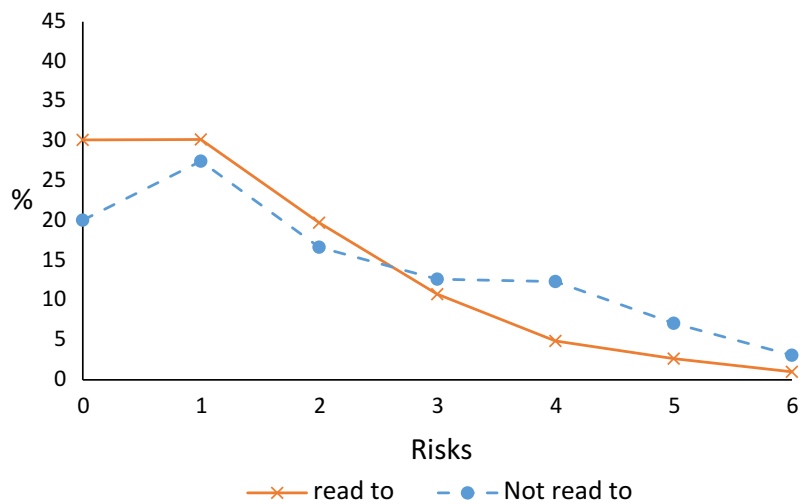

Fig. 3 Number of risks by reading status at age 6 
experienced 2 or more risks, compared with only $23.7 \%$ of children read to at least once in the last week.

$20 \%$ of children not read to at age 6 experienced 0 risks, compared with $30.1 \%$ of children read to at least once. $52.5 \%$ of children not read to at age 6 experienced 2 or more risks, compared with $39.4 \%$ of children read to at least once in the last week.

Table 7 describes the average number of risks for children at ages 2,4 and 6 by their reading status. Children not read to at age 2 were exposed to an average of 2.1 risks, compared with an average of 1.0 risks per child read to in the past week at age 2. Children not read to at age 4 were exposed to an average of 1.9 risks, compared with an average of 0.9 risks per child read to in the past week at age 4 . Children not read to at age 6 were exposed to an average of 1.5 risks, compared with an average of 1.0 risks per child read to in the past week at age 6 . The difference between children who were read to in the last week and children not read to whatsoever in the last week was statistically significant at each age.

There was an increased likelihood of not being read at each age as children were exposed an increasing number of risks. At age 2, being exposed to a single risk increased the likelihood of not being read to by an odds ratio of 3.3. Those children exposed to four or more risks had an odds ratio 21.4 relative to children exposed to zero risks at age 2 .

At age 4, being exposed to a single risk increased the likelihood of not being read to by an odds ratio of 1.8 . Those children exposed to four or more risks had an odds ratio 12.4 relative to children exposed to zero risks at age 4 .

Table 7 Distribution of risks by reading status at ages 2, 4, and 6

\begin{tabular}{llll}
\hline Age & $\begin{array}{l}\text { Mean risks, children not read to } \\
(95 \% \mathrm{CI})\end{array}$ & $\begin{array}{l}\text { Mean risks, children read to } \\
(95 \% \mathrm{CI})\end{array}$ & $\begin{array}{l}\text { Difference in risks } \\
(95 \% \mathrm{CI})\end{array}$ \\
\hline 2 & $2.09(1.93,2.25)$ & $1(0.97,1.03)$ & $1.09(0.95,1.22)^{* * *}$ \\
4 & $1.88(1.7,2.05)$ & $0.93(0.9,0.96)$ & $0.94(0.81,1.08) * * *$ \\
6 & $1.49(1.34,1.64)$ & $0.98(0.95,1.02)$ & $0.51(0.38,0.63) * * *$ \\
\hline
\end{tabular}

n.s. non-significant

$* P<.05 ; * * P<.01 ; * * * P<.001$

Table 8 Odds ratios for not being read to by cumulative risks at ages 2, 4 and 6

\begin{tabular}{llll}
\hline Cumulative risks & Age 2 & Age 4 & Age 6 \\
\hline 0 & 1.00 (Ref.) & 1.00 (Ref.) & 1.00 (Ref.) \\
1 & $3.25(2.06,5.15)^{* * *}$ & $1.77(1.21,2.59)^{* *}$ & $1.25(0.94,1.68)$ n.s. \\
2 & $6.34(3.97,10.12)^{* * *}$ & $3.27(2.19,4.89)^{* * *}$ & $1.45(1.02,2.07) *$ \\
3 & $13.16(8.1,21.41)^{* * *}$ & $6.93(4.55,10.55)^{* * *}$ & $3.32(2.31,4.79)^{* * *}$ \\
$4+$ & $21.36(12.47,36.56)^{* * *}$ & $12.39(7.63,20.11)^{* * *}$ & $3.9(2.48,6.14)^{* * *}$ \\
\hline
\end{tabular}

n.s. non-significant

$* P<.05$; ** $P<.01$; *** $P<.001$ 
There was an increased likelihood of not being read at age 6 to as children were exposed an increasing number of risks, although there was no statistically significant difference between children exposed to zero and one risk at age 6. Being exposed to a two risk increased the likelihood of not being read to by an odds ratio of 1.5. Those children exposed to four or more risks had an odds ratio 3.9 relative to children exposed to zero risks at age 6 (Table 8).

\section{Discussion}

This study had three aims: first, to document parent-child book reading behaviours at ages 2, 4 and 6 years; second, to investigate psychosocial risk factors for the absence of parent-child book reading at home; and third, to investigate the cumulative impact of psychosocial risk factors on the absence of parent-child book reading at home. From ages 2 to 6 , some 6-8\% of children were not read to at all. While the impact of individual risk factors varied across ages, cumulative risk mattered.

The study identified a group of children where exposure to multiple risks across all domains was a likely experience. This is consistent with other studies. Other authors have also found that economic disadvantage may co-occur with other risks, including limited social support, parental mental and physical health, educational level and intellectual ability, attitudes and cognitive readiness to parent coping style (Guralnick 2013). Sabates and Dex (2012) describe the distribution of ten risks within the UK Millennium Child Cohort Study. These risks included depression, physical disability, lack of basic skills, parental smoking during pregnancy, domestic violence and financial stress. They found that $28 \%$ of families with young children were facing two or more risks, with a smaller proportion of families exposed to numerous risks. Those children living in families with low income and multiple risks fared worse across cognitive development and social-emotional development at ages 3 and 5 than their peers at lower risk.

In an Australian context, Biddle and Seth-Purdie (2013) also considered multiple risk factors within the LSAC. Although they did not consider distinct groups within the sample, they found that children exposed to increasing numbers of risks were more likely to have low teacher-rated academic achievement, maths and literacy, and worse psychological wellbeing.

Poverty and overlapping risks are associated with worse cognitive and educational outcomes. Ayoub et al. (2009) found that children in poverty who live in comprehensively riskier systems have worse cognitive outcomes in the preschool-age groups. The current approach also highlights the complexities of overlapping patterns of child and family risk factors that are barriers to book reading. Results of meta-analyses of parent-child book reading interventions have revealed heterogeneity in effect sizes, favouring children from higher socioeconomic households (Manz et al. 2010; Mol et al. 2008). The findings from the current study suggest that addressing the absence of shared book reading requires a holistic approach that addresses the multiple risk contexts that explain why some parents do not read to their children. 
The policy implications of our findings require further exploration. On the one hand, it is helpful to know that a child who is not read to is more likely to be exposed to multiple risks. On the other hand, it is not immediately clear how one would identify which specific mix of risks a child is likely to be exposed to, on the basis of not being read to. Our previous work has shown that a well-fitted multivariate model does not necessarily predict child language outcomes across time with great precision, and we have grappled with the implications of this finding (Christensen et al. 2014; Zubrick et al. 2015). This issue remains unresolved in the current paper.

Our work highlights the need for services to take a holistic approach, with our key finding a remarkable overlap between child, maternal and family circumstances including child abilities, maternal psychological wellbeing and parenting style, cultural factors and socio-economic circumstances including income, education, employment and neighbourhood conditions.

In the Australian context, several programmes aim at helping families exposed to multiple disadvantage (Hilferty and Redmond 2009; McDonald et al. 2012; Taylor et al. 2015). The Home Interaction Program for Parents and Youngsters (HIPPY) is specifically targeted at children from disadvantaged communities and aims to improve their school readiness over a 2-year period concluding with the end of their first year at school (Lidedell et al. 2009, 2011). This programme uses a mix of home- and centre-based early childhood enrichments to help parents in building their children's school readiness. The Tasmanian Child and Family Centre programme takes a place-based approach to multiple disadvantage, offering a range of services to families experiencing disadvantage (Taylor et al. 2015). The Maternal Early Childhood Sustained Home-visiting (MECSH) programme is a structured programme of sustained nurse home visiting for families at risk of poorer maternal and child health and development outcomes. These targeted, place-based programmes are voluntary. Families are enrolled through word of mouth or recommendation from agencies. Access is usually determined by location. For example, HIPPY sites were selected based on measures of neighbourhood disadvantage and demographics, and the capacity of a local service provider and links with other programmes.

Internationally, there are a range of early childhood interventions aimed at addressing multiple disadvantage. Comparing these programmes is difficult because of the heterogeneity of approaches, but Guralnick (2013) reviews the characteristics of successful early childhood interventions. While the most consistent findings indicated the value of centre-based programmes for preschool-age children in the cognitive domain, these effects tend to be modest and to fade over time. He struggled to identify consistent patterns of success in home visiting programmes. Guralnick's (2013) own Developmental Systems Approach explicitly acknowledges the mix of children's social and cognitive competence, family patterns of interaction, family resources, and the interactions between them.

One take-away for service providers is to look broadly when considering patterns of risks - child, maternal and family risk factors may co-occur in complex patterns.

The results support early home learning programmes that address psychosocial risk factors that are barriers to active engagement in home learning activities such as 
parent-child book reading. The findings suggest that universal parent-child book reading interventions that focus solely on home learning activities may not meet the needs of families in which the absence of parent-child book reading signals a multiplicity of risk factors for child development.

\section{Conclusions}

For early childhood education and care service providers, asking parents how often they read to their children is an important question. In this study, the absence of book reading was a red flag that signalled the potential for a multiplicity of psychosocial risk factors in the child's home learning environment. Family-centred practice aims to support and strengthen child health, development and learning, starting with mutually agreed intervention priorities (Knoche et al. 2012). For parents who do not read to their children, their highest priority may not be reading to their children. For example, there may be other stressors or family priorities associated with the risk factors identified that prevent parents from devoting time to read to their child.

The design and delivery of parent-child book reading interventions needs to be grounded in knowledge about the psychosocial hazards associated with the absence of book reading and sensitivity to the multiple disadvantages and challenging circumstances that beset many families and children.

Acknowledgments This work was supported by a Grant from the Australian Research Council (CE140100027).

Open Access This article is distributed under the terms of the Creative Commons Attribution 4.0 International License (http://creativecommons.org/licenses/by/4.0/), which permits unrestricted use, distribution, and reproduction in any medium, provided you give appropriate credit to the original author(s) and the source, provide a link to the Creative Commons license, and indicate if changes were made.

\section{References}

Australian Bureau of Statistics. (2015). Factors influencing early childhood development in Tasmania. Cat 4261.6. Canberra: Australian Bureau of Statistics.

Ayoub, C., O'Connor, E., Rappolt-Schlictmann, G., Vallotton, C., Raikes, H., \& Chazan-Cohen, R. (2009). Cognitive skill performance among young children living in poverty: Risk, change, and the promotive effects of Early Head Start. Early Childhood Research Quarterly, 24(3), 289-305. doi:10. 1016/j.ecresq.2009.04.001.

Biddle, N., \& Seth-Purdie, S. (2013). Relationship between development risk and participation in early childhood education: How can we reach the most vulnerable children? H. C. Coombs Policy Forum \& Social Policy Institute Crawford School of Public Policy ANU College of Asia \& the Pacific. Canberra.

Christensen, D., Zubrick, S., R., Lawrence, D., Mitrou, F., \& Taylor, C. (2014). Risk factors for low receptive vocabulary abilities in the preschool and early school years in the Longitudinal Study of Australian Children. PLOS ONE, 9(7), e101476. doi:10.1371/journal.pone.0101476.

Duncan, G., Claessens, A., Huston, A., Pagani, L., Engel, M., Sexton, H., et al. (2007). School readiness and later achievement. Developmental Psychology, 43(6), 1428-1446. 
Edwards, B. (2012). Growing up in Australia: The Longitudinal Study of Australian Children. Family Matters, 91, 7-17.

Guralnick, Michael J. (2013). Developmental science and preventive interventions for children at environmental risk. Infants and Young Children, 26(4), 270-285. doi:10.1097/IYC. 0b013e3182a6832f.

High, P. C., Klass, P., Donoghue, E., Glassy, D., DelConte, B., Earls, D. L., et al. (2014). Literacy promotion: An essential component of primary care pediatric practice. Pediatrics, 134(2), 404-409. doi:10.1542/peds.2014-1384.

Hilferty, F., \& Redmond, G (2009). The implications of poverty on children's readiness to learn. Prepared for Australian Research Alliance for Children and Youth, West Perth.

Hutton, J. S., Horowitz-Kraus, T., Mendelsohn, A. L., DeWitt, T., \& Holland, S. K. (2015). Home reading environment and brain activation in preschool children listening to stories. Pediatrics,. doi:10.1542/ peds.2015-0359.

Kalb, G., \& van Ours, J. C. (2014). Reading to young children: A head-start in life? Economics of Education Review, 40, 1-24. doi:10.1016/j.econedurev.2014.01.002.

Knoche, L., Keely, D., \& Marvin, C. (2012). Fostering collaborative partnerships between early childhood professionals and the parents of young children. In R. Pianta (Ed.), Handbook of early childhood education (pp. 370-415). New York: The Guilford Press.

Lawrence, D., Mitrou, F., \& Zubrick, S. R. (2011). Non-specific psychological distress, smoking status and smoking cessation: United States National Health Interview Survey 2005. BMC Public Health, 11(256), 256. doi:10.1186/1471-2458-11-256.

Lidedell, M., Barnett, T., Diallo Roost, F., \& McEachran, J. (2011). Investing in our future: An evaluation of the national rollout of the Home Interaction Program for Parents and Youngsters (HIPPY). Department of Education Employment and Workplace Relations. Botherhood of St Lawrence, Fitzroy, Victoria.

Lidedell, M., Barnett, T., Hughes, J., \& Diallo Roost, F. (2009). The home learning environment and readiness for school: A 12-month evaluation of the Home Interaction Program for Parents and Youngsters (HIPPY). Victorian Department of Education and Early Childhood Development, Botherhood of St Lawrence, Fitzroy, Victoria.

Lugo-Gil, J., \& Tamis-LeMonda, C. S. (2008). Family resources and parenting quality: Links to children's cognitive development across the first 3 years. Child Development, 79(4), 1065-1085. doi:10.1111/j.1467-8624.2008.01176.x.

Manz, P. H., Hughes, C., Barnabas, E., Bracaliello, C., \& Ginsburg-Block, M. (2010). A descriptive review and meta-analysis of family-based emergent literacy interventions: To what extent is the research applicable to low-income, ethnic-minority or linguistically-diverse young children? Early Childhood Research Quarterly, 25(4), 409-431. doi:10.1016/j.ecresq.2010.03.002.

McDonald, M., Moore, T., \& Goldfeld, S. (2012). Sustained home visiting for vulnerable families and children: A literature review of effective programs. Prepared for Australian Research Alliance for Children and Youth. The Royal Children's Hospital Centre for Community Child Health, Murdoch Childrens Research Institute, Melbourne, Victoria.

Misson, S., \& Sipthorp, M. (2007). Wave 2 weighting and non-response. LSAC technical paper no. 5. Australian Institute of Family Studies. Australian Institute of Family Studies, Melbourne.

Mistry, R. S., Benner, A. D., Biesanz, J. C., Clark, S. L., \& Howes, C. (2010). Family and social risk, and parental investments during the early childhood years as predictors of low-income children's school readiness outcomes. Early Childhood Research Quarterly, 25(4), 432-449. doi:10.1016/j.ecresq. 2010.01.002.

Mol, S. E., Bus, A. G., de Jong, M. T., \& Smeets, D. J. (2008). Added value of dialogic parent-child book readings: a meta-analysis. Early Education and Development, 19(1), 7-26. doi:10.1080/ 10409280701838603.

Powell, D., \& Diamond, K. (2012). Promoting early literacy and language development. In R. Pianta (Ed.), Handbook of early childhood education (pp. 194-216). New York: The Guilford Press.

Sabates, R., \& Dex, S. (2012). Multiple risk factors in young children's development. CLS Cohort Studies. Centre for Longitudinal Studies, Institute of Education University of London.

SAS Institute Inc. (2002-2012). SAS for Windows Version 9.4. Cary, NC: SAS Institute Inc.

Sawyer, A. C., Chittleborough, C. R., Mittinty, M. N., Miller-Lewis, L. R., Sawyer, M. G., Sullivan, T., et al. (2015). Are trajectories of self-regulation abilities from ages 2-3 to 6-7 associated with academic achievement in the early school years? Child: Care, Health and Development, 41(5), 744-754. doi:10.1111/cch.12208. 
Senechal, M., \& LeFevre, J. (2002). Parental involvement in the development of children's reading skill: A five-year longitudinal study. Child Development, 73(2), 445-460.

Soloff, C., Lawrence, D., \& Johnstone, R. (2005). LSAC sample design. LSAC technical paper no. 1. Australian Institute of Family Studies, Melbourne.

Soloff, C., Lawrence, D., Misson, S., \& Johnstone, R. (2006). Wave 1 weighting and non-response. LSAC technical paper no. 3. Australian Institute of Family Studies, Melbourne.

Strazdins, L., Shipley, M., \& Broom, D. (2007). What does family-friendly really mean? Wellbeing, time, and the quality of parents' jobs. Australian Bulletin of Labour, 33(2), 202-225.

Strazdins, L., Shipley, M., Clements, M., O'Brien, L., \& Broom, D. (2010). Job quality and inequality: Parents' jobs and children's emotional and behavioral difficulties. Social Science and Medicine, 70, 2052-2060.

Taylor, C. L., Christensen, D., Lawrence, D., Mitrou, F., \& Zubrick, S. R. (2013). Risk factors for children's receptive vocabulary development from four to eight years in the Longitudinal Study of Australian Children. PLOS ONE, 8(9), e73046. doi:10.1371/journal.pone.0073046.

Taylor, C. L., Jose, K., Christensen, D., \& Van de Lageweg, W. (2015). Engaging, supporting and working with children and families in Tasmania's Child and Family Centres. Report on the impact of Centres on parents' use and experiences of services and supports in the early years. Telethon Kids Institute, Telethon Kids Institute. Perth, WA.

Thomas, E. (2006). Readiness to learn at school among five-year-old children in Canada. Statistics Canada: Ottawa.

United Nations Educational Scientific and Cultural Organisation (UNESCO). (2015). Education for all 2000-2015: Achievements and challenges. Paris: Author.

Zubrick, S. R., Lucas, N., Westrupp, E., \& Nicholson, J. (2014). Parenting measures in the Longitudinal Study of Australian Children: Construct validity and measurement quality, Waves 1 to 4. Canberra: Department of Social Services.

Zubrick, S. R., Smith, G., Nicholson, J. M., Sanson, A. V., Jackiewicz, T. A., \& the LSAC Research Consortium. (2008). Social research policy paper no. 34: parenting and families in Australia. ACT, Australian Government Department of Families, Housing, Community Services and Indigenous Affairs, Canberra.

Zubrick, S. R., Taylor, C. L., \& Christensen, D. (2015). Patterns and predictors of language and literacy abilities 4-10 years in the longitudinal study of Australian children. PLOS ONE, 10(9), e0135612. doi:10.1371/journal.pone.0135612. 